
and Aromatic Plants

An International Journal ISSN: 2619-9645 | e-ISSN: 2667-5722

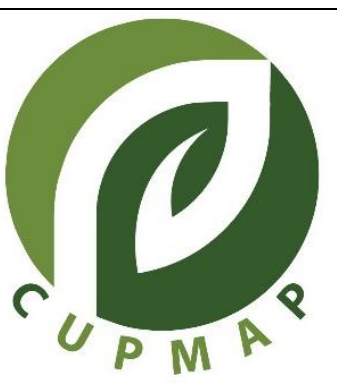

\title{
In-vitro Comparison Release Study of Novel Liposome and Conventional Formulation Containing Rosmarinus officinalis Extract
}

\author{
İsmail ASLAN $^{1,2,3 *}$ (iD), Ahmet Arif KURT ${ }^{4}$ (iD) \\ 1Department of Pharmaceutical Technology, Hamidiye Faculty of Pharmacy, \\ University of Health Sciences Turkey, 34668, Uskudar, Istanbul, Turkey \\ E-mail: eczismailaslan@gmail.com, ORCID ID: 0000-0001-7075-7103 \\ ${ }^{2}$ SFA R\&D Laboratories.,Technopark Blv, No:1 3A/Z01, 34906, Pendik, İstanbul, Turkey \\ ${ }^{3}$ SFA R\&D Laboratories,University of Health Sciences Teknopol, Pendik, İstanbul,Turkey \\ ${ }^{4}$ Vocational School of Health Services, Suleyman Demirel University, 32200 Isparta, Turkey \\ E-mail: aarifkurt@gmail.com, ORCID ID: 0000-0002-3490-0192 \\ *Corresponding author: eczismailaslan@gmail.com
}

\begin{abstract}
The purpose of this research article was to examine the impact of conventional Rosmarinus officinalis (without delivery systems) extract and extract incorporated liposomal delivery system on skin permeation velocity in vitro conditions was to determine whether there was a significant difference (in terms of duration) over the determined parameters.

The environment condition was $47 \mathrm{~mm}$ diameter with a capacity of $20 \mathrm{ml}$ in a water bath applied to the membrane surface in $37^{\circ} \mathrm{C}$ and using a double walled franz diffusion cell containing a syntetic polycarbonate membrane filter. 1., 3., 5., 10., 20., 40. in minutes and upto 160 minutes 50 rpm rotation speed (mimicking the application speed obtained from the skin) with classical methods and delivery named by calculating the transition rates of Rosmarinus officinalis extracts obtained by the alternative method through the diffusion cell.

As a result of the study, it was clearly determined that the mixture of Rosemary (Rosmarinus officinalis) extract in the liposomal carrier system at a volume ratio of $1: 1 \mathrm{had}$ an in vitro release rate of around $30 \%$ compared to $100 \%$ in 40 minutes, respectively, according to the traditional formula.
\end{abstract}

Key Words: Phytochemicals, Herbal liposomes, Rosmarinus officinalis, In-vitro release, Franz diffusion cell

(c) CUPMAP. All rights reserved.

\section{Introduction}

Herbal actives and plant sourced raw materials have been widely used against many health problem and cosmetic industry since centuries (Aslan, 2007). Rosmarinus officinalis $L$. is taxonomically included in the Lamiaceae family and has a pleasant scent, evergreen, perennial, branches reaching 50$110 \mathrm{~cm}$ in length, with leaves $1-3 \mathrm{~cm}$ in length. The upper surface of the leaves is dark green, soft and long hairy, the lower surface is light colored, with a dense soft hair, flowers in the form of a white star, densely hairy, and the fruit is brown in color (Mill, 1982; Baytop, 
1999). Rosemary is considered to be one of hundreds of species in the genus Salvia, native to the Mediterranean and Asia, but highly resistant in cool climates, evergreen (Drew, 2017). It is a plant of Mediterranean origin, loves the seaside and grows very well. The Latin meaning of the name Rosmarinus is the flower of the sea and is associated with the spread of the plant. Especially Turkey Adana, Hatay, Mersin, Antalya frequently seen in the area. Today, culture is carried out in many countries, some of them are in European countries such as France, Spain, Portugal, Italy, Greece, neighboring European countries, the Balkans, the USA and Mexico (Sönmez, 2008). It is a plant that spread around the world in time, it was brought to England by the Romans. It is very popular in the UK and has been used as a spice in meals, benefited from its medicinal properties, and used as a garden herb for its fragrance. In the field of pharmacy, Hippocrates, Galen, Dioscarides prescribed for stomach, flu and liver problems. It was used a lot in French pharmacies especially during the Renaissance and became the most prescribed herb.

When we look at the naming of the plant, Rosmarinus' name is the old name of the plant in classical Latin. The historical background of rosemary is included in cuneiform stone tablets from $5000 \mathrm{BC}$ and is mentioned in Materia Medica (Ambrose, 2016). When we look at the historical adventure of the plant, it is seen that it has records in the Chinese dynasty in $220 \mathrm{AD}$, and it is estimated that later the Romans came to European lands with the eastern expeditions (Madison, 2017). One of the first alcoholbased perfumes described as Hungarian water, Hungarian water was made from Rosemary. Leaves, branches and flowering tips are removed for use (Centre for Agriculture and Bioscience International, 2018). Rosemary leaves are used as flavouring in traditional Mediterranean cuisine and herbal teas can be made (Database USDA Nutrient, 2014). Another important point in terms of use with foods is that omega 3-rich oils that are prone to rancidity have been shown to increase shelf life and heat stability (Daniells, 2017).

In traditional medicine, it has been used orally as a tonic, in the case of constipation, anti-inflammatory, abdominal pain, headache, antispasmolytic, gout treatment, biliary therapy, diuretic, antirheumatic, antidepressant, external wound healing, antiscalp capping, hair loss (Baytop, 1999; González-Trujano et al., 2007). The dried leaves of the rosemary plant are maserated in olive oil and massaged into the hair roots, and the infusion prepared from its branches is used for diabetes. It is also recorded that it is used as a sedative as an infusion tea prepared from a mixture containing the leaves of the plant (Sarlkan, 2007).

The phenolic compounds responsible for the pharmacological activity of Rosmarinus officnalis are rosmarinic acid, carnosic acid and carnosol. Carnosic acid is the main component of the phenolic diterpenes in the rosemary plant (Kuhlmann and Röhl, 2006). The structure of carnosic acid is $\mathrm{C}_{20} \mathrm{H}_{28} \mathrm{O}_{4}$ and it comes from the terpenoids class, also known as isoprenoids or terpenes, it is one of the main polyphenolic diterpenes in the plant. In addition, many biological effects are seen; Anti-inflammatory and antiviral effects, nervous protective, anti-aging, antimicrobial, antiangiogenic, liver protective, antiadipogenic, antihyperglycemic and 
anticarcinogenic properties have also been reported (Bozic et al,, 2015; Jung et al, 2015).

Carnosic acid and carnosol are responsible for the antioxidant properties of the Rosmarinus officinalis plant and possibly protect chloroplasts and chloroplastic and perhaps other organelle membranes from oxidative stress. It has been reported that it has more antioxidant effect than butylhydroxytoluene and butylhydroxyanisole, which are generally used synthetic antioxidants.

Another important phenolic compound of Rosmarinus officinalis is Rosmarinic acid, which is the ester of caffeic acid and 3,4dihydroxyphenyllactic acid. Liver protective, anti-inflammatory,

antiangiogenic, antitumor, antidepressant, antineurodegenerative and HIV-1 inhibitory properties are known (Furtado et al, 2010). It has been shown in clinical studies that the diterpenes found in Rosmarinus officinalis plant induce various factors and also inhibit neuronal cell death (Habtemariam et al., 2016). In a study with Rosmarinus officinalis extract, the effects on mRNA expressions in the hippocampus and frontal lobe of rats were examined. It shows that the plant extract causes long-term memory improvement, which can be explained in part by the inhibition of AChE activity in the rat brain. (Ozarowski et al., 2013). In a study conducted with rosemary plant, it was stated that it can limit the weight gain that develops due to fatty onset and prevent metabolic disorders related to obesity. (Sedighi, 2014). It is thought to reduce body weight and fat ratio by inducing the pancreas by inhibition of lipase activity. (Harach et al., 2010). In a research on colon cancer cells, the apoptosis of the cells increased thanks to Rosmarin extract and carnosic acid. It significantly increased the expression of Nrf2 and inhibited HCT116 heterograft tumor formation (Yan et al., 2015). In another cytotoxic study with rosemary extract, its effect on cancers in different organs was examined. In a study conducted with lung cancer, colon cancer, breast cancer and cervical cancer, rosemary was found to have the highest cytotoxic activity on lung cancer (Alanazi, 2016). In an in vivo study on the potency of R. officinalis in gastric ulcer, it was observed that gastric ulcerations were prevented in male rats whose stomach was stimulated with 70\% alcohol. (Amaral et al., 2013). Its use as a fragrance, the essential oil of Salvia Rosmarinus is burned as incense to spread fragrant body perfumes or aroma in a room, and is used in shampoo and cleaning products. Phytochemically, Rosemary essential oil contains 10-20\% camphor and contains a number of phytochemicals such as rosmarinic acid, camphor, caffeic acid, ursolic acid, betulinic acid, carnosic acid, and carnosol (Vallverdu, 2014).

The epidermis, which is the upper level of the skin structure, consists of the stratum corneum (SC) followed by the lucidum, granulosum, spinosum and basal membrane, followed by the dermis and hypodermis layer (Biju et al., 2006). Transdermal delivery systems must overcome the inherent properties of the skin structure. Transdermal delivery systems must overcome the natural properties of the stratum corneum as a skin barrier. The stratum corneum acts as a protective layer that prevents the penetration of foreign compounds from the external environment into the skin and also prevents the skin's moisture loss (Atmakuri and Dathi, 2010). 
Liposomes are a new generation carrier system with both a hydrophilic head and a lipophilic chain part, which increases their absorption from the skin by trapping different active ingredients in their structure (Aslan et al., 2020; Duman et al., 2014). Thanks to their properties that mimic the skin and cell membranes, they are preferred in many areas ranging from cosmetics to biotechnology, biochemistry and physiology to food supplements (Ethemoğlu et al., 2017; Yazıcı et al., 2011; Günal et al., 2019). A liposome is a useful tool for transporting herbal active ingredients to the inner layers of the skin by passing through the skin barrier due to its double-layered structure obtained from phospholipids similar to the skin structure (Uhumwangho and Okor, 2005) Phospholipids, which are components of liposomes, have many advantages as a carrier of active ingredients such as strong tissue affinity, biodegradability and low toxicity (Yadav et al., 2011). It is advantageous for liposomal delivery systems to provide the effect of increasing the bioavailability while minimizing the toxicity of the active ingredient in the delivery of plant origin active ingredients at an optimum rate. Advantages of liposomal delivery systems are;

- Liposomes are used in active ingredient encapsulation systems because of their advanced features.

- The liposome can entrapped both lipophilic and water soluble active ingredients. For that reason, as an active ingredient transporter, the liposome can indiscriminately carry active ingredients via cellular structure.

- The liposomal formulation can provide a sustained and controlled formulation release and increase active ingredient solubility.

Table 1. Herbal liposomal formulations

\begin{tabular}{|c|c|c|c|c|c|}
\hline Herbal Source & Active materials & $\begin{array}{l}\text { Biological } \\
\text { Activity }\end{array}$ & $\begin{array}{c}\begin{array}{c}\text { Applications of liposome } \\
\text { formulations }\end{array} \\
\end{array}$ & Year & References \\
\hline Pueraria lobota & Puerarin & $\begin{array}{c}\text { Anti-arrhythmia } \\
\text { Activity }\end{array}$ & $\begin{array}{c}\text { These formulations modify } \\
\text { their surface charge and } \\
\text { membrane integrity }\end{array}$ & 2007 & $\begin{array}{c}\text { Rong and } \\
\text { JuQun, } 2007\end{array}$ \\
\hline Nux vomica & $\begin{array}{l}\text { Strychnine, } \\
\text { Brucine }\end{array}$ & $\begin{array}{c}\text { Anti-tumour, } \\
\text { analgesic and anti- } \\
\text { inflammatory }\end{array}$ & $\begin{array}{l}\text { Activities Increase stability } \\
\text { of formulations }\end{array}$ & 2010 & $\begin{array}{l}\text { Chen et al., } \\
2010\end{array}$ \\
\hline Myrtus communis & $\begin{array}{c}\text { 1,8-cineole, } \\
\text { linalool, myrtenyl } \\
\text { acetate, } \\
\text { myrtenol }\end{array}$ & $\begin{array}{l}\text { Antioxidant and } \\
\text { antimicrobial } \\
\text { activity }\end{array}$ & Increase in its activities & 2008 & $\begin{array}{c}\text { Gortzi et al., } \\
2008\end{array}$ \\
\hline $\begin{array}{l}\text { Diospyros montana } \\
\text { Roxb }\end{array}$ & Diospyrin & $\begin{array}{l}\text { Anti-cancer } \\
\text { activity }\end{array}$ & $\begin{array}{l}\text { Enhancement of its anti- } \\
\text { tumour effect }\end{array}$ & 2005 & $\begin{array}{c}\text { Hazra et al., } \\
2005\end{array}$ \\
\hline $\begin{array}{l}\text { Artemisia } \\
\text { arborescens } \mathrm{L} .\end{array}$ & $\begin{array}{c}\text { Artemisia } \\
\text { arborescens }\end{array}$ & Antiviral activity & $\begin{array}{l}\text { Increase in antiviral activity } \\
\text { and stability }\end{array}$ & 2005 & $\begin{array}{c}\text { Fadda at al., } \\
2005 \\
\end{array}$ \\
\hline Magnolia officinalis & Magnolol & $\begin{array}{c}\text { Inhibiting vascular } \\
\text { smooth muscle } \\
\text { cells (VSMCs) } \\
\text { proliferation }\end{array}$ & $\begin{array}{c}\text { Enhance the therapeutic } \\
\text { efficacy }\end{array}$ & 2008 & Chen 2008 \\
\hline $\begin{array}{l}\text { Purchased From } \\
\text { Sigma Chemicals }\end{array}$ & Quercetin & $\begin{array}{l}\text { Antioxidant } \\
\text { activity }\end{array}$ & $\begin{array}{c}\text { Enhance therapeutic } \\
\text { efficacy }\end{array}$ & 2010 & $\begin{array}{c}\text { Ghosh et al., } \\
2010\end{array}$ \\
\hline
\end{tabular}


Franz diffusion cells have become very important in research studies of the passage of drugs and cosmetics through the skin. Although there are question marks in terms of analytical validation, studies conducted in recent years, it can be said that transition through the skin in in vitro conditions without the need for animal studies provides an advantage for researchers in all respects. Synthetic polycarbonate membrane filters reduce variability and increase reproducibility (Fern et al., 2010, Andrews et al., 2013).

a
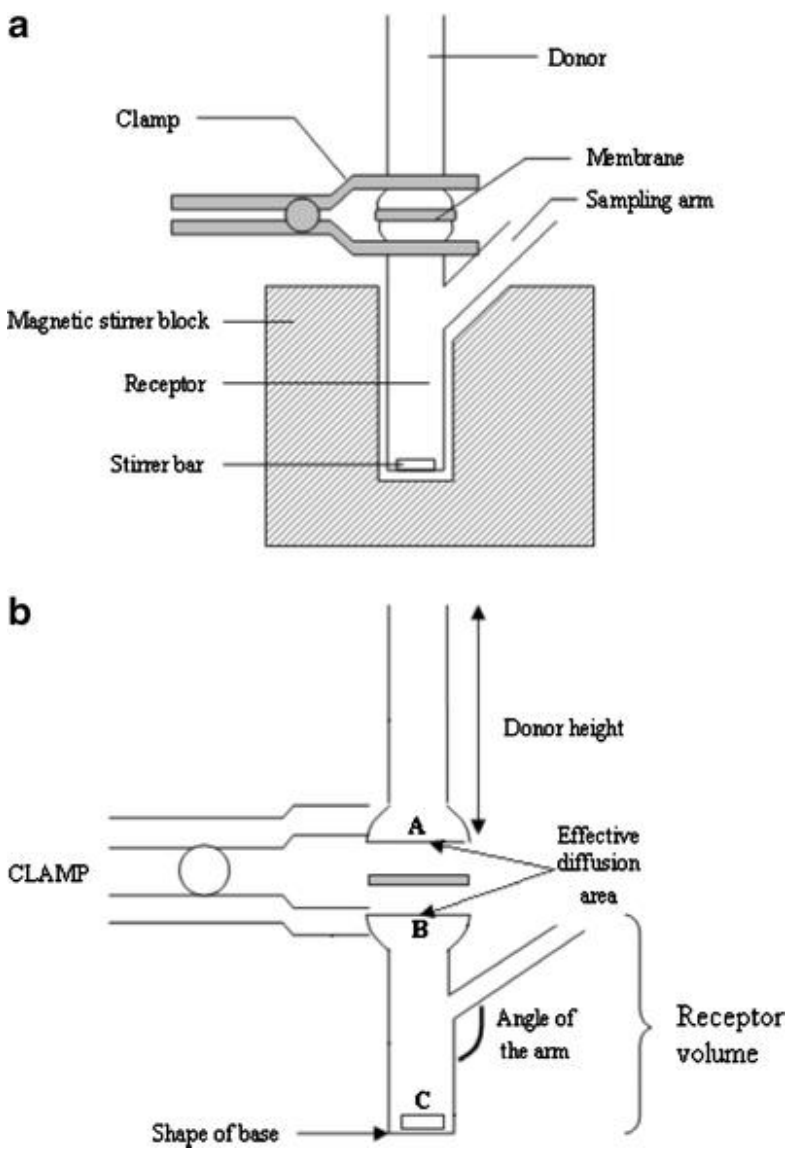

Figure 1. Shematic Representation of a Franz Diffusion Cell System for In Vitro Release Studies (Andrews et al., 2013)

In this research paper was to indicate the effect of conventional Rosmarinus officinalis (without delivery systems) extract and liposomal delivery system incorporated extract on skin permeation velocity in vitro conditions was to determine whether there was a significant difference in terms of duration over the determined parameters.

\section{Material and Methods}

\subsection{Materials}

Hydrogenated Soybean Phoshatidylcholine (HSP) and phospholipids were provided from LIPOID (Germany). Cholesterol (CHOL) was obtained from Sigma (UK). Rosmarinus officinalis extract was provided from İnan Tarım (Turkey). All other chemical reagents were of analytical purity. Franz diffusion cell was used in order to determine the absorbtion rate of delivery system (Permegear, USA).

\subsection{Preparation of Herbal Liposome Formulations}

Liposome carrier systems were designed by thin film preparation method (Gunal et al., 2019). Firstly, liposome dispersions (HSP and Cholesterol) were designed by dissolving the $40 \mu \mathrm{mol} \mathrm{mL} \mathrm{m}^{-1}$ of phosphatidylcholine and lipophilic components in $30 \mathrm{~mL}$ chloroform in a round flask. Chloroform solvent was evaporated using a rotary evaporator under 0-100 mbar pressure to form a thin film over the wall of the flask. Also, ethanol was accurately evaporated using rotary evaporator from plant extract. The thin film was then solved over a water bath with buffer Rosmarinus officinalis extract as $1: 1 \mathrm{v} / \mathrm{v}$ ratio. Optimized liposome formulation was selected according to previous experimental study (Aslan et al., 2020) 


\subsection{In vitro Release Study}

All permeation experiments have been done using an endless dosage regimen. This test was a single application and covers the application starting from 1 minute to 40 minutes and then the following results. 50 rpm of the new formulations obtained by conventional method and liposomal formulations (imitating the application speed to the skin), 1.3.5.10.20. 40. and 160 minutes, respectively.

The permeation values were compared by calculating the velocities of passage through the diffusion cell in minutes and up to 160 minutes. Briefly, the working principle is based on the application of the tested product approximately $1 \mathrm{ml}$ once to the jacketed Franz diffusion cell in $37^{\circ} \mathrm{C}$, phosphate buffer solution at $\mathrm{pH}: 7.4$. This product simulates keeping in contact with the skin for up to 1 minute and up to 40 minutes. Afterwards, samples were taken at specified times and the results were recorded with the measurements in the UV spectrophotometer. Agilent 8453 (USA) was used for the determination of absorbance in UV spectrophotometer and branded analyzer, which is widely preferred in UV analysis in many research studies. Since the skin is known to have tight intercellular connections around $220 \mathrm{~nm}$ and also a polycarbonate membrane filter was preferred because of inert material. Permegear branded equipment (Standard 25mm Jacketed Franz Cell) was used for the diffusion cell. The amount of test material applied to each cell was $1 \mathrm{ml}$, the receptor volume was $20 \mathrm{ml}$ and the amount taken at certain times was $0.5 \mathrm{ml}$. The standard calibration curve of rosmarinic acid has been extracted. By taking samples, their absorbance was measured at $272 \mathrm{~nm}$. Bypassing from absorbances to \% concentration, the concentration at which $100 \%$ of the product releases was determined. Herbal liposome formulation (HLF) and conventional formulation containing Rosmarinus officinalis extract (CFR) were compared according to in vitro release study via Franz diffusion cell.

\section{Results and Discussion}

\subsection{Calibration Curve Results of Rosmarinic acid}

Rosmarinic acid was a major component of Rosmarinus officinalis extract to determine UV Spectral analyze. For that reason, calibration curve has been presented and calculated between $0.05 \mathrm{mM}$ and $0.25 \mathrm{mM}$ according to the results in Figure 2 at 323nm.

\subsection{In vitro Release Study Results}

In vitro release is an important parameter of absorbtion for topical herbal liposomal carrier models. According to in vitro release study results, HLF formulation presented better penetration behaviour compare to CFR at the end of the 160 minutes in vitro release study.

All data were given Table 2 and Figure 3. 


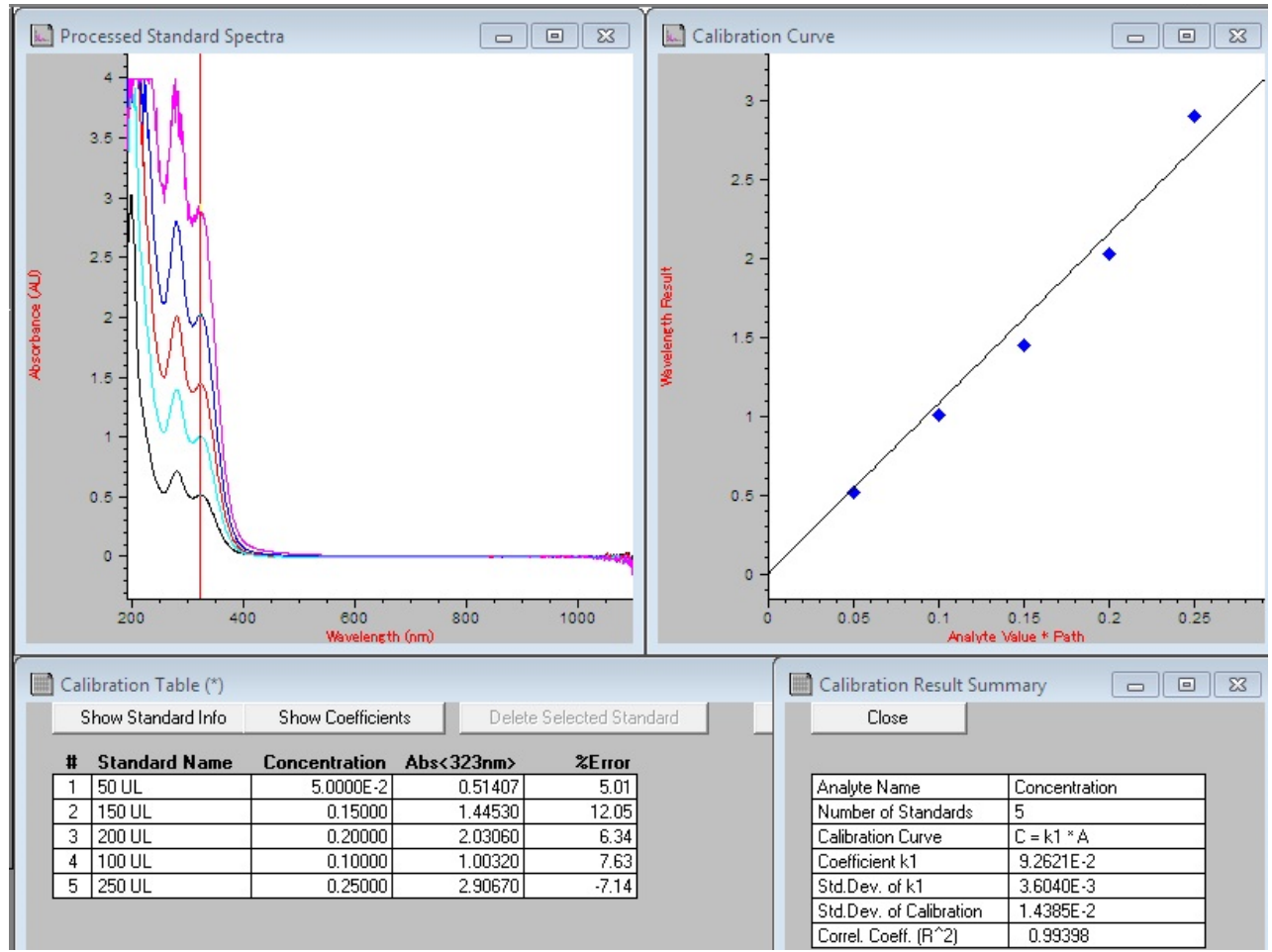

Figure 2. Calibration curve of Rosmarinic acid at $323 \mathrm{~nm}$.

Table 2. Cumulative release table of HLP and CFR formulation $(n=6)$.

\begin{tabular}{|c|c|c|c|c|c|c|c|c|c|c|c|c|}
\hline $\begin{array}{c}\text { Time } \\
\text { (min.) }\end{array}$ & \multicolumn{4}{|c|}{ HLP (Herbal Liposome) } & \multicolumn{4}{c|}{ CFR (Conventional Rosemary Extract) } \\
\hline 0 & 0 & 0 & 0 & 0 & 0 & 0 & 0 & 0 & 0 & 0 & 0 & 0 \\
\hline 1 & 3 & 3,22 & 2,33 & 4,96 & 3,96 & 5,13 & 1,02 & 1,35 & 0,88 & 1,08 & 1,04 & 1,12 \\
\hline 3 & 15,06 & 15,22 & 14,76 & 15,28 & 14,86 & 15,88 & 2,12 & 2,06 & 2,16 & 2,22 & 2,1 & 2,24 \\
\hline 5 & 37,44 & 36,76 & 35,98 & 36,52 & 37,96 & 37,82 & 4,94 & 5,52 & 5,38 & 5,2 & 5,14 & 5,28 \\
\hline 10 & 55,26 & 54,88 & 55,63 & 55,74 & 54,9 & 54,58 & 10,04 & 9,92 & 10,16 & 10,02 & 9,98 & 9,84 \\
\hline 20 & 87,98 & 88,54 & 88,44 & 88,7 & 87,66 & 89,02 & 21,63 & 20,74 & 20,48 & 21,02 & 20,96 & 20,8 \\
\hline 40 & 97,66 & 98,88 & 99,66 & 97,84 & 98,55 & 99,24 & 34,3 & 36,54 & 35,68 & 35,4 & 35,34 & 35,28 \\
\hline 160 & 100,98 & 99,8 & 98,9 & 99,96 & 100,02 & 99,62 & 60,82 & 60,9 & 58,28 & 57,6 & 61,29 & 59,06 \\
\hline
\end{tabular}

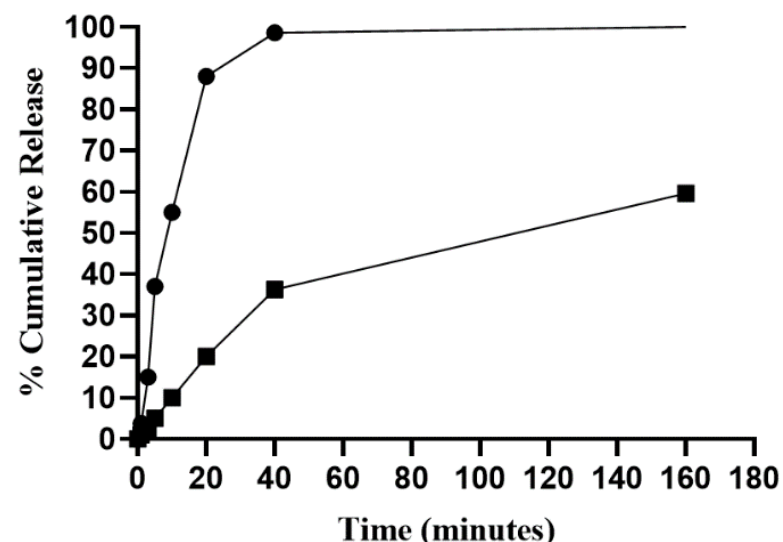

- HLP (Herbal liposome)

CFR (Conventional

Rosemary extract)

Time (minutes)

Figure 2. Cumulative in vitro release study result of HLF and CFR formulations $(n=6)$. 


\section{Conclusion}

In this research; spectroscopic analysis and in vitro release studies were considered to select the better carrier system for Rosemary extract formulation. For that reason, HLF formulation was selected depending on the release behaviour (Table2 and Figure 3). Size controlled liposome formulation showed that it was better penetration enhancer for the topical delivery systems compare to the conventional extract systems.

The objective of this study is to develop a topical delivery system which is containing herbal actives, with innovative formulation. As a result of the study, it was clearly determined that the mixture of rosemary (Rosmarinus officinalis) extract in the liposomal carrier system at a volume ratio of 1: 1 compared with the conventional formula has a very high in vitro release rate of 160 minutes, even absorbed within minutes. Ex vivo and cell culture studies will be planned in near future.

\section{Acknowledgements}

The authors would like to special thanks to MSc. Cosm. Bekir Çakıcıl SFA R\&D Laboratories, İstanbul, Turkey) for their valuable support to our research paper.

\section{Author Contributions}

Ísmail ASLAN devised the project, the main conceptual ideas and proof outline.

Ahmet Arif KURT worked out almost all of the technical details, and performed the numerical calculations for the suggested experiment. All authors discussed the results and commented on the manuscript.

\section{Conflicts of Interest}

We declare that there are no matters of conflict of interest. No funding was received for this article; we did not receive any sponsorship.

\section{References}

1. Alanazi, A. M. (2016). The cytotoxicity effect of rosemary and myrrh extracts on cancer cell lines (Doctoral dissertation, Tennessee State University).

2. Aslan, İ , Kurt, A . (2020). Characterization and Optimization of Phytosome Formulation Containing Alcohol-free Umckalin from Pelargonium sidoides . Current Perspectives on Medicinal and Aromatic Plants (CUPMAP), 3 (1) , 49-53

https://doi.org/10.38093/cupmap.737878

3. Aslan, I. (2007) Plants and Cosmetics. Fitomed, 3, 49-51.

4. Atmakuri LR, Dathi S. (2010), Current trends in herbal medicines. J Pharm Res.; 3(1):109-113.

5. Biju SS, Talegaonkar S, Mishra PR, Khar RK. (2006) Vesicular system: an overview. Indian J Pharm Sci.; 68(2): 141-153.

6. Božić, D., Papaefthimiou, D., Brückner, K., de Vos, R.C., Tsoleridis, C.A., Katsarou, D., Papanikolaou, A., Pateraki, I., Chatzopoulou, F.M., Dimitriadou, E., Kostas, S., Manzano, D., Scheler, U., Ferrer, A., Tissier, A., Makris, A.M., Kampranis, S.C. and Kanellis, A.K. (2015). Towards elucidating carnosic acid biosynthesis in Lamiaceae: functional characterization of the three first steps of the pathway in Salvia fruticosa and Rosmarinus officinalis. PLoS One, 10(5), e0124106.

7. Centre for Agriculture and Bioscience International.,(2018), "Rosmarinus officinalis (rosemary)".

8. Chen C. (2008), Inhibiting the vascular smooth muscle cells proliferation By EPC and DPPC liposome encapsulated magnalol. J Chin Inst Chem Eng.;39:407-411.

9. Chen J, Chen Z, Wang W. (2010), Ammonium sulphate gradient loading of brucine into liposome: effect of phospholipid composition on entrapment efficiency and physicochemical properties in vitro. Drug Dev Ind Pharm.;36:245253.

10. Daniells, Stephen (2017). "Oregano, rosemary extracts promise omega-3 preservation". Food Navigator.

11. Database USDA Nutrient, (2014),"Nutrition Facts - Dried rosemary, one teaspoon (1 g)". nutritiondata.com. Conde Nast, , version SR-21..

12. Dawn C P Ambrose,(2016), Leafy Medicinal Herbs: Botany, Chemistry, Postharvest Technology and Uses by Dawn Ambrose, 216, 210-11

13. Drew, Bryan T.; González-Gallegos, Jesús Guadalupe; Xiang, Chun-Lei; Kriebel, Ricardo; Drummond, Chloe P.; Walker, Jay B.; Sytsma, Kenneth J. (2017). "Salvia united: The greatest good for the greatest number". Taxon. 66(1): 133-145. 
14. Duman, G., Aslan, İ., Özer, A. Y., İnanç, İ., Taralp, A. (2014). Liposome, gel and lipogelosome formulations containing sodium hyaluronate. Journal of liposome research, 24(4), 259-269. https://doi.org/10.3109/08982104.2014.90730 5.

15. Ethemoglu, M. S., Seker, F. B., Akkaya, H., Kilic, E., Aslan, I., Erdogan, C. S., Yilmaz, B. (2017). Anticonvulsant activity of resveratrol-loaded liposomes in vivo. Neuroscience, 357, 12-19. https://doi.org/10.1016/j.neuroscience.2017.05 .026.

16. Fadda AM, Sinico C, Lai F, Logu AD. (2005), Liposomal incorporation of artimisia arborescenceL. Essential oil and in vitro antiviral activity. Eur J Pharma Biopharma.;59:161-8.

17. Furtado, R.A., De Araujo, F.R.R., Resende, F.A., Cunha, W.R. and Tavares, D.C. (2010). Protective effect of rosmarinic acid on V79 cells evaluated by the micronucleus and comet assays. Journal of Applied Toxicology, 30(3), 254-259

18. Ghosh D, Ghosh S, Sarkar S, Ghosh A, Das N, Das Saha K, et al. (2010) Quercetin in vesicular delivery systems: evaluation in combating arsenic-induced acute liver toxicity associated gene expression in rat model. Chem Biol Interact:;186:61-71.

19. Gortzi O, Lalas S, Chinou L. (2008), Reevaluation of bioactivity and antioxidant activity of myrtuscommunis extract before and after encapsulation in liposome. Eur Food Res Technol.;226:583-90

20. Gunal, M. Y., Ayla, Ş., Bedri, N., Beker, M. Ç., Çağlayan, A. B., Aslan, İ. ... Kılıç, Ü. (2019). The effects of topical liposomal resveratrol on incisional and excisional wound healing process. Turkderm-Turkish Archives of Dermatology and Venerology, 53(4), 128-134. http://doi.org/10.4274/turkderm.galenos.2019. 82612.

21. Habtemariam, S. (2016). The therapeutic potential of rosemary (Rosmarinus officinalis) diterpenes for Alzheimer's disease. EvidenceBased Complementary and Alternative Medicine, 1-15.

22. Harach, T., Aprikian, O., Monnard, I., Moulin, J., Membrez, M., Béolor, J. C., ... ve Darimont, C. (2010). Rosemary (Rosmarinus officinalis L.) leaf extract limits weight gain and liver steatosis in mice fed

23. Hazra B, Kumar B, Biswas S, Pandey BN, Mishra KP. (2005) Enhancement of the tumour inhibitory activity, in vivo, of diospyrin, a plantderived quinonoid, through liposomal encapsulation. Toxicol Lett.;157:109-17

24. Jung, K.J., Min, K. J., Bae, J.H. and Kwon, T.K. (2015). Carnosic acid sensitized TRAIL-mediated apoptosis through down-regulation of c-FLIP and Bcl-2 expression at the post translational levels and CHOP-dependent up-regulation of DR5, Bim, and PUMA expression in human carcinoma caki cells. Oncotarget, 6(3), 1556).

25. Kuhlmann, A. and Röhl, C. (2006). Phenolic antioxidant compounds produced by in vitro. Cultures of Rosemary (Rosmarinus officinalis.) and their antiinflammatory effect on lipopolysaccharide-activated microglia. Pharmaceutical Biology, 44(6), 401-410.) .

26. Madison D. (2017)The Illustrated Encyclopedia of Fruits, Vegetables, and Herbs: History, Botany by Deborah Madison, p.266

27. Ng, SF., Rouse, J.J., Sanderson, F.D. et al. Validation of a Static Franz Diffusion Cell System for In Vitro Permeation Studies. AAPS PharmSciTech 11, 1432-1441 (2010). https://doi.org/10.1208/s12249-010-9522-9

28. Ozarowski, M., Mikolajczak, P. L., Bogacz, A., Gryszczynska, A., Kujawska, M., Jodynis-Liebert, J., ... ve Bartkowiak-Wieczorek, J. (2013). Rosmarinus officinalis L. leaf extract improves memory impairment and affects acetylcholinesterase and butyrylcholinesterase activities in rat brain. Fitoterapia, 91, 261-271.

29. Rong G, JuQun X. (2007) Studies on molecular interection between puerarin and PC liposomes. Chinese Sci Bull.;52:2612-7

30. Sedighi, R. (2014). Carnosic Acid Enriched Rosemary Extract Prevents Obesity and Metabolic Syndrome in High-Fat Diet-Fed Mice (Doctoral dissertation, North Carolina Agricultural and Technical State University).

31. Uhumwangho MU, Okor RS. 2005 Current trends in the production and biomedical applications of liposomes: a review. J Biomed Sci.; 4: 9-21. http://doi.org/10.4314/jmbr.v4i1.10663

32. Vallverdú-Queralt, Anna; Regueiro, Jorge; Martínez-Huélamo, Miriam; Rinaldi Alvarenga, José Fernando; Leal, Leonel Neto; LamuelaRaventos, Rosa M. (2014). "A comprehensive study on the phenolic profile of widely used culinary herbs and spices: Rosemary, thyme, oregano, cinnamon, cumin and bay". Food Chemistry. 154: 299-307.

33. Yadav D, Suri S, Choudhary AA, Sikender M, Hemant, Beg NM, et al. (2011), Novel approach: Herbal remedies and natural products in pharmaceutical science as nano drug delivery systems. Int J Pharm Tech.;3:3092-116.

34. Yazici, M., Duman, G., Aslan, I., Durucan, A., \& Sahin, F. (2011). The antifungal activity of liposomal ointment formulation of essential oil of Satureja hortensis. Current Opinion in Biotechnology, (22), S108. http://doi.org/10.1016/j.copbio.2011.05.345 